\title{
TATA RUANG DAN PENILAIAN DAMPAK LINGKUNGAN INDUSTRI DI BANGKALAN PASCA PEMBANGUNAN JEMBATAN SURAMADU BERDASARKAN POTENSI DAERAH
}

\author{
ISSA DYAH UTAMI, ${ }^{1}$ WENY FINDIASTUTI, ${ }^{1}$ DWI KUSWANTO, ${ }^{2}$ DAN MOSES L. SINGGIH ${ }^{3}$ \\ ${ }^{1}$ Jurusan Teknik Industri, Fakultas Teknik, Universitas Trunojoyo Madura \\ 2 Jurusan Teknik Informatika, Fakultas Teknik, Universitas Trunojoyo Madura \\ ${ }^{3}$ Jurusan Teknik Industri, Fakultas Teknologi Industri, Kampus ITS Sukolilo Surabaya \\ E-mail: issa_2008@trunojoyo.ac.id
}

\begin{abstract}
ABSTRAK
Pembangunan Jembatan Suramadu yang menghubungkan Pulau Jawa dengan Madura akan membuka peluang bagi Kabupaten Bangkalan berkembang menjadi daerah lokasi kegiatan perindustrian di jawa Timur. Pembentukan kawasan industri akan terwujud apabila ada investor yang bersedia menginvestasikan modalnya di Kawasan Industri Bangkalan. Metode klustering analisis, faktor analisis, skoring penilaian resiko dampak lingkungan dengan konsep Risk Management diterapkan dalam proses pembentukan tata ruang. Hasil Penelitian ini menunjukkan bahwa berdasarkan potensi industri, wilayah Bangkalan terbagi dalam enam kawasan. Kawasan I merupakan daerah yang paling tepat untuk dijadikan kawasan industri dan pusat perdagangan. Penelitian ini juga menghasilkan suatu standarisasi model sistem informasi yang dapat memberikan informasi tentang tata ruang industri dan klustering jenis industri yang dapat didirikan berdasarkan potensi daerah, serta analisa rencana pengelolaan berdasarkan dampak lingkungan di Kabupaten Bangkalan. Hasil penelitian ini diharapkan mampu menarik investor dan lembaga keuangan untuk menginvestasikan modalnya di kawasan Industri Kabupaten Bangkalan sehingga masyarakat dapat meningkatkan kesejahteraannya.
\end{abstract}

Kata kunci: taman industri, klaster, analisa lingkungan

\begin{abstract}
The development of Suramadu Bridge that connects Java Island and Madura Island opens the opportunity for Bangkalan Regency to be one of Industrial Park at East Java Province. This could be realized if there are many investors who invest their capital and build their industry at the industrial Park. The Clustering analysis and Scoring Risk analysis are used in this research. The results of this study indicate that based on the industrial potential, Bangkalan region is divided into six regions. Region I is the most appropriate area to serve industrial and commercial center. The study also build a Standardized Information System as a guide for the investors to invest their capital. This contains information about Industry Spatial Planning and Clustering based on area potency of bangkalan Regency and Environmental Impact.
\end{abstract}

Key word: industrial park, clustering, environmental analysis

\section{PENDAHULUAN}

Pembangunan Jembatan Suramadu yang menghubungkan Pulau Jawa dengan Madura akan membuka peluang bagi Kabupaten Bangkalan berkembang menjadi daerah lokasi kegiatan perindustrian di jawa Timur. Kabupaten Bangkalan direncanakan sebagai daerah industri sebagai upaya untuk mengganti biaya investasi pembangunan Jembatan Suramadu yang cukup besar (Laporan Feasibility Study Jembatan Suramadu Tahun 2002). Sesuai dengan Keputusan Presiden yang telah ditetapkan pada Tahun 2001 mengenai rencana pembangunan Jembatan Suramadu, pembangunan ini diharapkan akan menjadi katalisator pendorong perkembangan sektor industri di Kabupaten Bangkalan.

Jembatan Suramadu ini juga diharapkan berfungsi sebagai stimulator pertumbuhan wilayah di Pulau Madura. Kabupaten Bangkalan dinilai belum mendukung sebagai daerah lokasi kegiatan sektor industri karena kekuatannya hanya ada pada aspek tenaga kerja dan aspek pertanahannya saja, di mana persediaan tanah untuk guna lahan industri hampir mencapai $50.000 \mathrm{Ha}$. Dukungan dari masyarakat akan meningkat bila rencana pembangunan infrastruktur setempat dapat terealisasi dan mendukung sebagai daerah lokasi kegiatan industri saat pembangunan Jembatan 
Suramadu, dilihat dari lima aspek faktor lokasi yaitu transportasi, pertanahan, tenaga kerja, aglomerasi dan fasilitas dasar (Paramita, 2008).

Penelitian ini diharapkan dapat menghasilkan suatu standarisasi model sistem informasi yang dapat memberikan informasi tentang tata ruang industri dan klustering jenis industri yang dapat didirikan berdasarkan potensi daerah, serta analisa rencana pengelolaan dampak lingkungan berdasarkan potensi daerah di Kabupaten Bangkalan. Hasil penelitian ini diharapkan mampu menarik investor dan lembaga keuangan untuk menginvestasikan modalnya di kawasan Industri Kabupaten Bangkalan sehingga masyarakat dapat meningkat kesejahteraannya.

\section{METODE}

Penelitian ini menggunakan metode klustering analisis, faktor analisis, skoring analisa resiko dampak lingkungan dengan konsep Risk Management dan pembentukan model sistem informasi untuk merancang tata ruang industri berdasarkan potensi daerah. Teknik pengumpulan data yang dilakukan dalam penelitian ini adalah observasi atau pemantauan secara langsung pada area kawasan, pengumpulan data sekunder dari pemerintah daerah setempat dan penyebaran kuesioner untuk mengetahui potensi daerah dan skoring analisa dampak lingkungan. Data yang dikumpulkan adalah potensi daerah pada sektor industri kecil, pertanian, pertambangan, perikanan, perkebunan, pendidikan dan industri pariwisata. aerah yang dianalisa potensinya dengan urutan nomor satu sampai dengan delapan belas adalah Kecamatan Kamal, Labang, Kwanyar, Modung, Blega, Konang, Galis, Tanah Merah, Tragah, Socah, Bangkalan, Burneh, Arosbaya, Geger, Kokop, Tanjung Bumi, Sepulu dan Klampis.

\section{Penentuan Potensi Kawasan}

Penelitian ini menggunakan software Ms. Excel, Minitab dan SPSS. Langkah pertama data diuji apakah layak untuk diolah dengan menggunakan analisa standarisasi, jika layak maka dilakukan analisa faktor yang kemudian akan dilanjutkan dengan analisa klaster untuk mengelompokkan kelas dengan analisa diskriminan. Hasil uji kelayakan faktor jika menunjukkan tidak layak selanjutnya diolah dengan metode analisa klaster untuk mengelompokkan kelaskelas yang memiliki kesamaan dan diuji kelayakan hasil pengklasteran tersebut dengan analisa diskriminan.

Langkah yang dilakukan pada tahap pengolahan data adalah standarisasi data. Data atau variabel dalam penelitian ini tidak memiliki satuan yang sama, untuk itu perlu distandarisasi dengan formula. Langkah-langkah dalam tahap ini sebagai berikut (a) Menentukan variabel yang akan dianalisis; (b) Menguji variabel dan ekstraksi variable menggunakan uji Barlett dan nilai KMO (KeiserMeyer-Olkin) dengan nilai $\alpha=0,05$ dengan Hipotesis $:$ Ho = data belum memadai untuk dianalisa lebih lanjut dan $\mathrm{H}_{1}$ = data telah memadai untuk dianalisa lebih lanjut; (c) Nilai MSA (Measures of Sampling Adequacy) untuk ekstraksi. Jika MSA < 0,5 maka variabel tersebut dikeluarkan. Jika ada dua variabel mempunyai MSA < 0,5 maka yang dikeluarkan adalah variabel dengan nilai MSA terkecil kemudian dianalisis kembali. Proses berhenti sampai semua variabel mempunyai nilai MSA $>0,5$.

Langkah penilaian MSA meliputi (1) Melakukan pemfaktoran; (2) Melakukan rotasi faktor untuk memperjelas variabel yang masuk ke dalam faktor tertentu menggunakan metode ortogonal rotation varimax; (3) Membuat skor faktor dengan metode regresi $f_{j}-L^{\prime} S^{-1}\left(x_{j}-\bar{x}\right)$. Proses selanjutnya melakukan pengklasteran terhadap beberapa kriteria dengan metode cluster analysis yang telah dipilih dalam langkah faktor analisis. Penelitian ini digunakan metode keterkaitan lengkap (complete linkage method atau furthers) sama dengan metode keterkaitan tunggal. Perbedaan metode complete linkage method dengan linkage method yang lain adalah metode ini menggunakan pendekatan jarak maksimum atau jarak terjauh terjauh, di mana jarak antara satu klaster dan klaster lain diukur berdasarkan jarak terjauh antar anggota-anggota kluster.

Tahapan-tahapan dalam Skoring List sebagai berikut : (a.) Risk List, pada tahap ini dilakukan identifikasi aspek dan penilaian dampak lingkungan melalui penyebaran kuesioner; (b) Risk-action List, pada tahap ini dilakukan skoring aspek dan dampak lingkungan dengan mengadopsi parameter skoring dari BAPEDAL. Tahap Risk-action List digunakan untuk mengetahui tingkat signifikansi aspek lingkungan terhadap faktor bisnis dan faktor lingkungan di kawasan industri. Kuesioner skoring diberikan kepada para pakar yang dianggap mengetahui dan mampu memberikan penilaian tentang dampak lingkungan kawasan industri di Kabupaten Bangkalan; (c) Risk-startegy Mode, pada tahap ini usulan rancangan tata kelola kawasan industri yang ramah terhadap lingkungan akan dirumuskan berdasarkan data dan informasi yang telah diperoleh sebelumnya.

Desain model dan sistem informasi Kawasan Industri kabupaten Bangkalan dilakukan dengan perancangan sistem dengan komponen-komponen sistem yang telah dianalisis pada tahap sebelumnya. Tahap-tahap perancangan sistem sebagai berikut: 
(1) Analisis Sistem: menganalisis dan mendefinisikan masalah dan kemungkinan solusinya untuk sistem informasi dan proses organisasi; (2) Analisis terhadap level pembuat keputusan (manajemen organisasi): menganalisa organisasi, fungsi dan informasi yang dibutuhkan beserta informasi yang dihasilkan; (3) Analisis terhadap aliran informasi : mengidentifikasi informasi apa yang diperlukan, siapa yang memerlukan, dari mana asalnya, (3) Analisis terhadap input dan output; (4) Perancangan Sistem: merancang output, input, struktur file, program, prosedur, perangkat keras dan perangkat lunak yang diperlukan untuk mendukung sistem informasi; (5) Pembangunan dan Testing system: membangun perangkat lunak yang diperlukan untuk mendukung dan melakukan testing secara akurat. Melakukan instalasi dan testing terhadap perangkat keras dan mengoperasikan perangkat lunak; (6) Implementasi Sistem: beralih dari sistem lama ke sistem baru, melakukan pelatihan dan panduan seperlunya; (7) Operasi dan Perawatan: mendukung operasi informasi dan melakukan perubahan atau tambahan fasilitas; (8) Evaluasi Sistem: mengevaluasi sejauh mana telah dibangun dan seberapa bagus telah dioperasikan; (9) Analisa aspek kelayakan sistem informasi dengan kriteria kelayakan teknis, ekonomi, operasi dan jadwal.

\section{HASIL DAN PEMBAHASAN}

Data yang telah diuji kelayakan dengan menggunakan standarisasi data kemudian diolah dengan metode analisa klaster untuk mengelompokkan kelas-kelas yang memiliki kesamaan dan diuji kelayakan hasil pengklasteran tersebut dengan analisa diskriminan. Pengelompokan disesuaikan dengan kondisi wilayah dan jarak antar wilayah, sehingga menghasilkan pengelompokan kawasan berdasarkan potensi dan analisa kondisi lingkungan dari berbagai industri yang saat ini berada di kawasan tersebut, seperti pada tabel 2 .

Kawasan I yang terdiri dari kecamatan Kamal, Labang, Kwanyar dan Tragah. Kawasan ini terletak didekat pelabuhan Kamal dan jembatan Suramadu. Kawasan ini merupakan daerah dengan sebagian besar penduduknya bermata pencaharian sebagai pedagang. Karakteristik tanah didaerah ini kurang cocok untuk area pertanian sehingga kawasan ini lebih tepat untuk dijadikan sentra kawasan industri dan perdagangan.

Skor rata-rata dampak lingkungannya sebesar 26260 pada kawasan I hal ini menunjukkan dampak lingkungan pada daerah ini masih cukup tinggi karena di daerah ini terdapat industri pengolahan bahan kimia dan bahan bangunan. Jumlah industri

Tabel 1. Output pengolahan data dengan Minitab

\begin{tabular}{|c|c|c|c|c|c|c|c|}
\hline \multicolumn{8}{|c|}{ Cluster Analysis of Observations : L1: L2: L3: L4: L5:L6:U1:U2:U3:U4:K1:K2:K3 } \\
\hline \multicolumn{8}{|c|}{ Euclidean Distance, Ward Linkage } \\
\hline \multicolumn{8}{|c|}{ Amalgamation Steps } \\
\hline Step & $\begin{array}{c}\text { Number of } \\
\text { clusters }\end{array}$ & $\begin{array}{c}\text { Similarity } \\
\text { Level }\end{array}$ & Distance level & \multicolumn{2}{|c|}{ Clusters joined } & New cluster & $\begin{array}{c}\text { Number of obs. in } \\
\text { new cluster }\end{array}$ \\
\hline 1 & 17 & 57,23 & 6,146 & 9 & 13 & 9 & 2 \\
\hline 2 & 16 & 55,62 & 6,377 & 2 & 9 & 2 & 3 \\
\hline 3 & 15 & 54,24 & 6,575 & 16 & 18 & 16 & 2 \\
\hline 4 & 14 & 51,89 & 6,913 & 12 & 15 & 12 & 2 \\
\hline 5 & 13 & 49,86 & 7,204 & 2 & 17 & 2 & 4 \\
\hline 6 & 12 & 45,38 & 7,788 & 2 & 3 & 2 & 5 \\
\hline 7 & 11 & 45,80 & 7,848 & 4 & 16 & 4 & 3 \\
\hline 8 & 10 & 35,10 & 9,325 & 5 & 12 & 5 & 3 \\
\hline 9 & 9 & 30,46 & 9,993 & 1 & 2 & 1 & 6 \\
\hline 10 & 8 & 26,30 & 10,590 & 1 & 4 & 1 & 9 \\
\hline 11 & 7 & 25,29 & 10,734 & 5 & 8 & 5 & 4 \\
\hline 12 & 6 & 23,04 & 11,058 & 5 & 10 & 5 & 5 \\
\hline 13 & 5 & 22,50 & 11,136 & 7 & 14 & 7 & 2 \\
\hline 14 & 4 & 17,89 & 11,734 & 6 & 7 & 6 & 3 \\
\hline 15 & 3 & 16,80 & 11,955 & 5 & 6 & 5 & 8 \\
\hline 16 & 2 & $-1,84$ & 14,634 & 5 & 11 & 5 & 9 \\
\hline 17 & 1 & $-29,11$ & 18,552 & 1 & 5 & 1 & 18 \\
\hline \multicolumn{8}{|c|}{ Final partition } \\
\hline \multicolumn{8}{|c|}{ Number of clusters: } \\
\hline & $\begin{array}{l}\text { Number of } \\
\text { observations }\end{array}$ & $\begin{array}{l}\text { Within cluster } \\
\text { sum of squares }\end{array}$ & $\begin{array}{c}\text { Average } \\
\text { distance from } \\
\text { centroid }\end{array}$ & $\begin{array}{c}\text { Maximum } \\
\text { distance from } \\
\text { centroid }\end{array}$ & & & \\
\hline Cluster 1 & 18 & 867,000 & 6,765 & 10,086 & & & \\
\hline
\end{tabular}


yang terdapat dikawasan ini masih sangat rendah dan pengelolaan potensi lingkungannya juga belum maksimal. Kawasan I lebih tepat untuk dijadikan pusat kawasan industri Madura dilihat dari letak dan potensi alamnya.

Kawasan II yang terdiri dari kecamatan Arosbaya, Tanjung bumi, Sepulu dan Klampis merupakan kawasan pariwisata dan sentra industri kecil dan menengah batik Madura. Kawasan ini memiliki potensi industri meubel dengan bahan baku kayu jati lokal dan industri kecil pengolahan makanan hasil laut. Skor penilaian dampak lingkungan di kawasan ini rata-rata sebesar 18786. Pengelolaan limbah yang dihasilkan oleh produksi batik pada IKM tersebut masih kurang baik.

Hasil industri kecil kawasan II sangat berpotensi untuk menunjang kemajuan pariwisata Kabupaten Bangkalan dan pulau Madura. Hasil IKM batik dan makanan laut yang dihasilkan mempunyai karateristik khusus yang menunjukkan spesifikasi dan keindahan pulau Madura. Apabila rencana penataan ruang kawasan industri dipusatkan di Kawasan I, maka Kawasan II dapat mensuplai hasil produksi IKM nya untuk menambah omset penjualan dan meningkatkan efeisiensi proses distribusi dan pemasaran produk.

Kawasan III yang terdiri dari kecamatan Galis dan Geger merupakan daerah dengan potensi peternakan, perkebunan dan hasil hutan. Kawasan ini juga memiliki potensi jumlah penduduk yang besar sehingga dapat menunjang kebutuhan tenaga kerja dalam pembentukan industrialisasi di Madura. Hasil peternakan yang dominan dikawasan ini adalah peternakan sapi dan kambing. Hasil perkebunannya adalah ubi jalar, jambu mete, mangga, durian dan pisang.

Hasil perkebunan yang terdapat dikawasan III saat ini masih belum diolah dan dimanfaatkan dengan maksimal. Industrialisasi di Madura diharapkan hasil perkebunan dapat dimaksimalkan potensinya. Peningkatan nilai hasil bumi dapat dilakukan dengan mengolahnya menjadi makanan olahan dengan proses produksi yang sesuai dengan standart dan daerah pemasarannya dapat diperluas hingga keluar pulau Madura.

Skor penilaian dampak lingkungan pada kawasan III ini rata-rata sebesar 55125. Skor dampak lingkungan pada kawasan ini cukup tinggi karena kawasan ini, terutama di kecamatan Geger terdapat industri pengolahan bahan bangunan yaitu batu bata, bata merah, genteng dan pengergajian kayu. Usaha pengelolaan dan konservasi lingkungan perlu dilakukan Kawasan III untuk mencegah kerusakan lingkungan yang akan ditimbulkan oleh penggunaan potensi sumber daya alam oleh industri-industri tersebut.
Kawasan IV terdiri dari kecamatan Tanah Merah. Kecamatan ini mempunyai potensi daerah berupa hasil perikanan darat dan payau, hasil peternakan sapi, kambing, ayam buras dan berbagai jenis unggas lainnya serta hasil perkebunan yang menonjol di daerah ini adalah jeruk, mangga, durian, belimbing. Kawasan ini juga mempunyai potensi sumber daya alam berupa bahan galian $\mathrm{C}$ yang belum dimanfaatkan.

Industri yang ada dikawasan ini saat ini adalah IKM konveksi dan penggergajian kayu. Hasil kuesioner penilaian dampak lingkungan pada kawasan IV ini sebesar 33075. Skor dampak lingkungan kawasan ini juga tergolong tinggi karena pada kawasan belum ada pengelolaan dampak lingkungan terhadap berbagai industri-industri yang ada di kawasan ini.

Kawasan V terdiri dari Kecamatan Bangkalan dan Socah. Kecamatan Bangkalan yang juga merupakan ibu kota Kabupaten Bangkalan lebih banyak memiliki potensi dan sarana di bidang pariwisata dan industri jasa. Kawasan ini lebih tepat apabila dikembangkan wilayah perdagangan, industri jasa dan sarana pariwisata.

Jembatan Suramadu yang telah dioperasikan dan rencana pemerintah untuk mengembangkan kawasan industri di Kabupaten Bangkalan menjadikan Kawasan V di Bangkalan akan lebih tepat untuk dikembangkan sarana penginapan atau hotel, sarana transportasi dan industri jasa lainnya misal pertokoan, rumah makan, pasar tradisional dan pasar modern. Kecamatan Socah dimasukkan dalam klaster ini karena wilayahnya berdekatan dengan kecamatan Bangkalan. Kecamatan Socah mempunyai potensi industri IKM makan hasil olahan perkebunan keripik mlinjo dan IKM pengolahan makanan hasil laut yaitu kerupuk Terung.

Kawasan $\mathrm{V}$ juga mempunyai potensi untuk dikembangkan industri rokok, industri bata putih, kapur, arang dan batik Tulis. Skor kuesioner analisa dampak lingkungan, pada kawasan ini mencapai 19110. Skor dampak lingkungan dikawasan ini tergolong masih tinggi karena belum adanya pengelolaan dan implementasi analisa dampak lingkungan pada industri yang ada dikawasan.

Kawasan terakhir yaitu kawasan VI terdiri dari Kecamatan Burneh, Kokop dan Blega. Kawasan ini mempunyai potensi dibidang pertanian. Kecamatan Blega mempunyai luas area sebesar 11.792 hektar dan curah hujan tinggi sehingga hasil pertanian terutama padi dan jagung sangat tinggi di kecamatan ini. Kecamatan Kokop merupakan kecamatan terluas di Kabupaten Bangkalan.

Kecamatan Kokop mempunyai potensi sumberdaya alam bahan galian $\mathrm{C}$ terutama 
Tabel 2. Potensi daerah pada enam kawasan di Kabupaten Bangkalan

\begin{tabular}{|c|c|c|c|}
\hline Kawasan & Wilayah & Potensi Daerah & AMDAL \\
\hline Kawasan I & $\begin{array}{l}\text { Kamal } \\
\text { Labang } \\
\text { Kwanyar } \\
\text { Tragah } \\
\end{array}$ & $\begin{array}{l}\text { Perdagangan } \\
\text { Industri jasa }\end{array}$ & $\begin{array}{l}\text { Skor hasil penilaian dampak lingkungan rata-rata sebesar } \\
26260\end{array}$ \\
\hline Kawasan II & $\begin{array}{l}\text { Arosbaya } \\
\text { Tanjung bumi } \\
\text { Sepulu } \\
\text { Klampis }\end{array}$ & $\begin{array}{l}\text { Industri Kecil Menengah (IKM) } \\
\text { Industri hasil laut }\end{array}$ & Skor penilaian dampak lingkungan rata-rata sebesar 18786 \\
\hline Kawasan III & $\begin{array}{l}\text { Konang } \\
\text { Galis } \\
\text { Geger } \\
\text { Modung }\end{array}$ & $\begin{array}{l}\text { Peternakan sapi dan kambing } \\
\text { Hasil perkebunan ubi jalar, } \\
\text { jambu mente, mangga, durian, } \\
\text { pisang } \\
\text { Hasil hutan dan jumlah } \\
\text { penduduk yang besar }\end{array}$ & Skor penilaian dampak lingkungan rata-rata sebesar 55125 \\
\hline Kawasan IV & Tanah Merah & $\begin{array}{l}\text { Hasil perikanan } \\
\text { Hasil peternakan } \\
\text { Hasil perkebunan }\end{array}$ & Skor penilaian dampak lingkungan rata-rata sebesar 33075 \\
\hline Kawasan V & $\begin{array}{l}\text { Socah } \\
\text { Bangkalan }\end{array}$ & $\begin{array}{l}\text { Industri pariwisata } \\
\text { Hasil perkebunan salak } \\
\text { Industri jasa }\end{array}$ & Skor penilaian dampak lingkungan rata sebesar 19110 \\
\hline Kawasan VI & $\begin{array}{l}\text { Burneh } \\
\text { Kokop } \\
\text { Blega }\end{array}$ & $\begin{array}{l}\text { Hasil perkebunan mlinjo, } \\
\text { Peternakan itik } \\
\text { Bahan galian C: batu putih } \\
\text { Hasil pertanian padi, jagung dan } \\
\text { ubi jalar }\end{array}$ & Skor penilaian dampak lingkungan rata sebesar 77175 \\
\hline
\end{tabular}

batu gamping yang cukup tinggi yaitu sebesar 6.996.783.432 $\mathrm{m}^{3}$. Kecamatan ini juga terdapat banyak industri pembuatan genteng, penggergajian kayu, pande besi dan industri kecil pembuatan kerajinan tas. Kecamatan Burneh mempunyai potensi peternakan itik dan unggas.

Hasil skor penilaian rata-rata dampak lingkungan pada daerah ini sebesar 77175. Hal ini dikarenakan pada daerah ini terdapat industri pengolahan bahan galian berupa industri genteng dan batu bata serta terdapat industri penggergajian kayu. Hasil analisa pada masing-masing wilayah dapat dilihat pada tabel 2 di bawah ini.

Kawasan I yang terdiri dari kecamatan Kamal, Labang, Kwanyar dan Tragah merupakan kawasan yang selama ini memiliki potensi dibidang perdagangan. Kawasan ini wilayahnya berdekatan dengan jembatan Suramadu dan Pelabuhan Kamal. Potensi pertanian dikawasan ini tergolong rendah karena karakteristik tanahnya yang mengandung kapur serta kondisi perairan yang kurang cocok untuk pengembangan pertanian.

Hasil penilaian dampak lingkungan dikawasan ini tepat untuk didirikan kawasan industri sebagai pengembangan kawasan industri di wilayah Surabaya dan gresik. Sarana infrastruktur berupa Jembatan Suramadu dan pelabuhan kamal sangat mendukung dalam pengembangan kawasan industri dan perdagangan di wilayah ini.
Hasil penelitian potensi wilayah kemudian dijadikan sebagai acuan dalam perancangan sistem informasi Kawasan Industri Bangkalan. Sistem informasi terlihat pada gambar 4. Sistem informasi berisi gambar peta perencanaan tata ruang kawasan industri di Kawasan I yang berdasarkan hasil penelitian, kawasan ini memiliki potensi sebagai kawasan industri.

Tata ruang kawasan industri ini diatur berdasarkan kebutuhan luas masing-masing area yaitu sekitar 3000 sampai dengan 21.000 kilometer tiap industri. Kawasan ini juga dilengkapi dengan area hijau dan peristirahatan, sarana oleh raga, perkantoran dan kebutuhan umum lainnya, misalnya

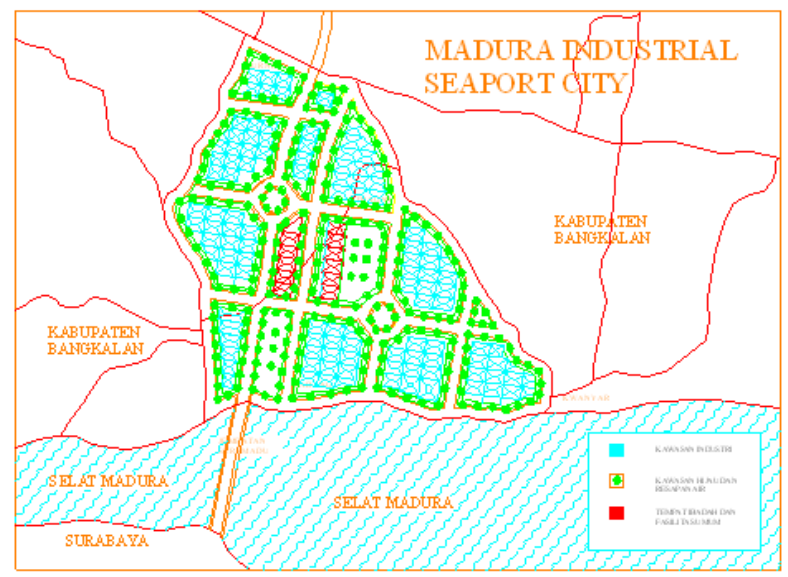

Gambar 2. Peta hasil perencanaan tata ruang kawasan Industri Bangkalan 
stasiun pengisian bahan bakar, sarana ibadah dan sarana kesehatan seperti terlihat pada gambar 3 .

Model sistem informasi kawasan industri juga menyajikan informasi tentang potensi-potensi seluruh wilayah di Kabupaten Bangkalan sesuai dengan hasil pengklasteran dalam enam kawasan. Informasi ini diharapkan dapat dijadikan bahan pertimbangan bagi para investor untuk merencanakan industri apa yang akan didirikan atau dikembangkan di Kabupaten Bangkalan.

\section{SIMPULAN}

Hasil penelitian menujukkan Kabupaten Bangkalan terbagi menjadi enam Kawasan sesuai dengan Potensi yang dimiliki oleh masing-masing kawasan Kawasan I memiliki potensi perdagangan dan industri jasa, Kawasan II memiliki potensi untuk dikembangkan Industri Kecil dan industri hasil laut, Kawasan III memiliki potensi peternakan perkebunan dan hasil hutan, Kawasan IV memilki potensi perikanan, peternakan dan perkebunan, Kawasan $\mathrm{V}$ berpotensi untuk dikembangkan industri pariwisata dan industri jasa dan Kawasan VI memiliki potensi hasil bahan galian C. Hasil penilaian dampak lingkungan pada keenam kawasan menunjukkan bahwa skor dampak lingkungan pada semua kawasan masih tinggi terutama pada berbagai industri kecil dan menengah yang ada di daerah tersebut. Sistem informasi yang dihasilkan dalam penelitian ini menghasilkan model sistem informasi yang mendeskripsikan potensi dan dampak lingkungan pada masing-masing wilayah. Hasil pengembangan tata ruang kawasan industri ini dirancang berdasarkan analisa pada potensi wilayah di Kabupaten Bangkalan. Hasil penelitian ini diharapkan dapat menjadi bahan pertimbangan bagi pemerintah daerah dalam menyusun perencanaan tata ruang dan kebijakan dibidang industri juga diharapkan dapat dijadikan sebagai bahan informasi bagi para investor dari dalam dan luar negeri.

\section{DAFTAR PUSTAKA}

Apple, J.M. 1963. Plant Layout and Material Handling. New York: Ronald Press Company.

BPS. 2009. "Bangkalan Dalam Angka 2009. Bangkalan In Figures 2009".

Badan Litbang Departemen Pekerjaan Umum. 2006. Pedoman Teknis Pengembangan Kawasan Industri (Industrial Estate) di Daerah. Jakarta.

Brata W, Nur Ubaya 2003. Analsis Pengembangan Wilayah Industri Dengan Pendekatan Klaster Industri (Studi Kasus: Klaster Industri Susu Kawasan Andalan Sukabumi). Thesis ITB. Bandung.

Christina Esti Susanti, 2007. Segmentasi Berdasarkan Analisis Klaster Sebagai Strategi Pengembangan

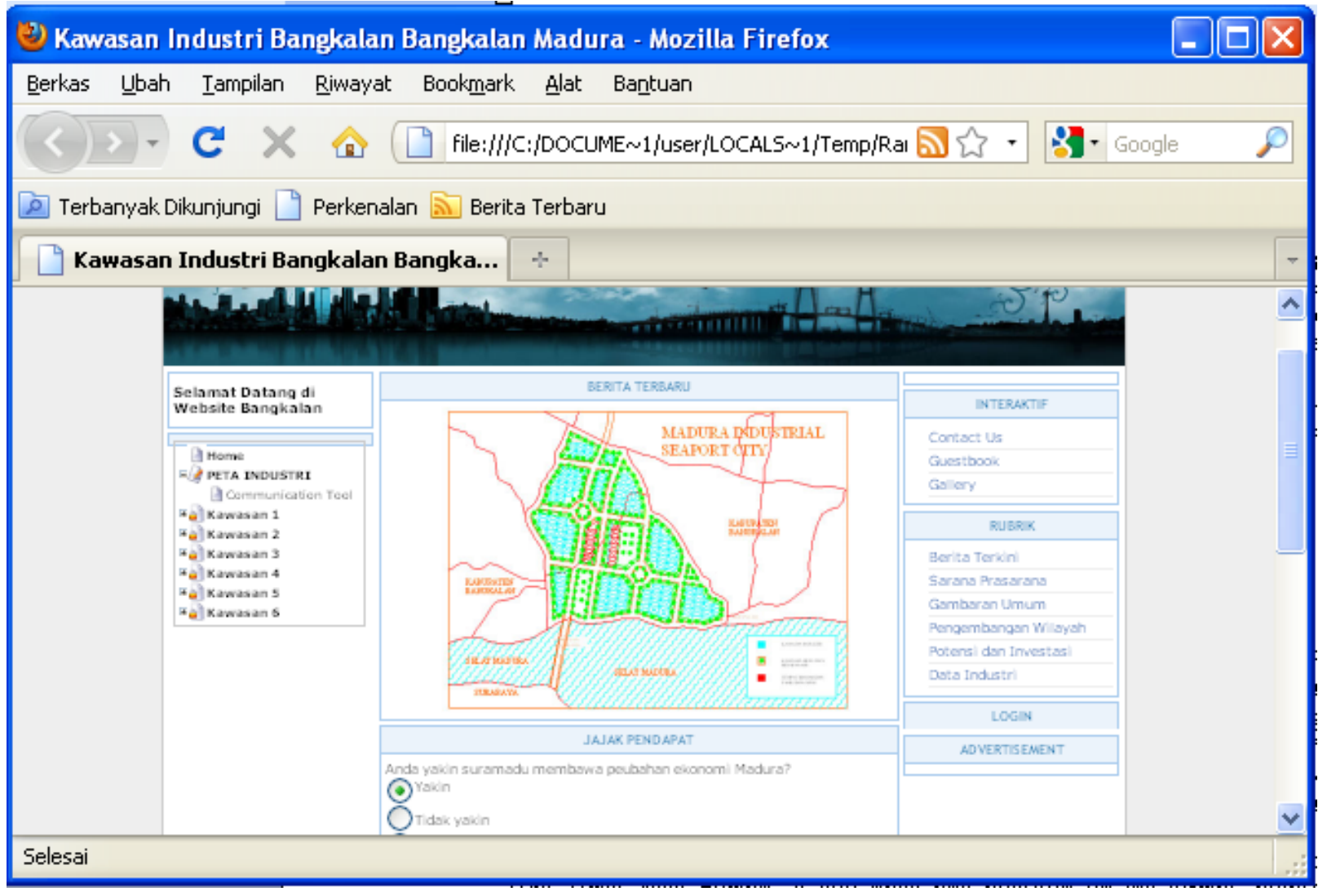

Gambar 3. Model sistem informasi perencaan kawasan industri 


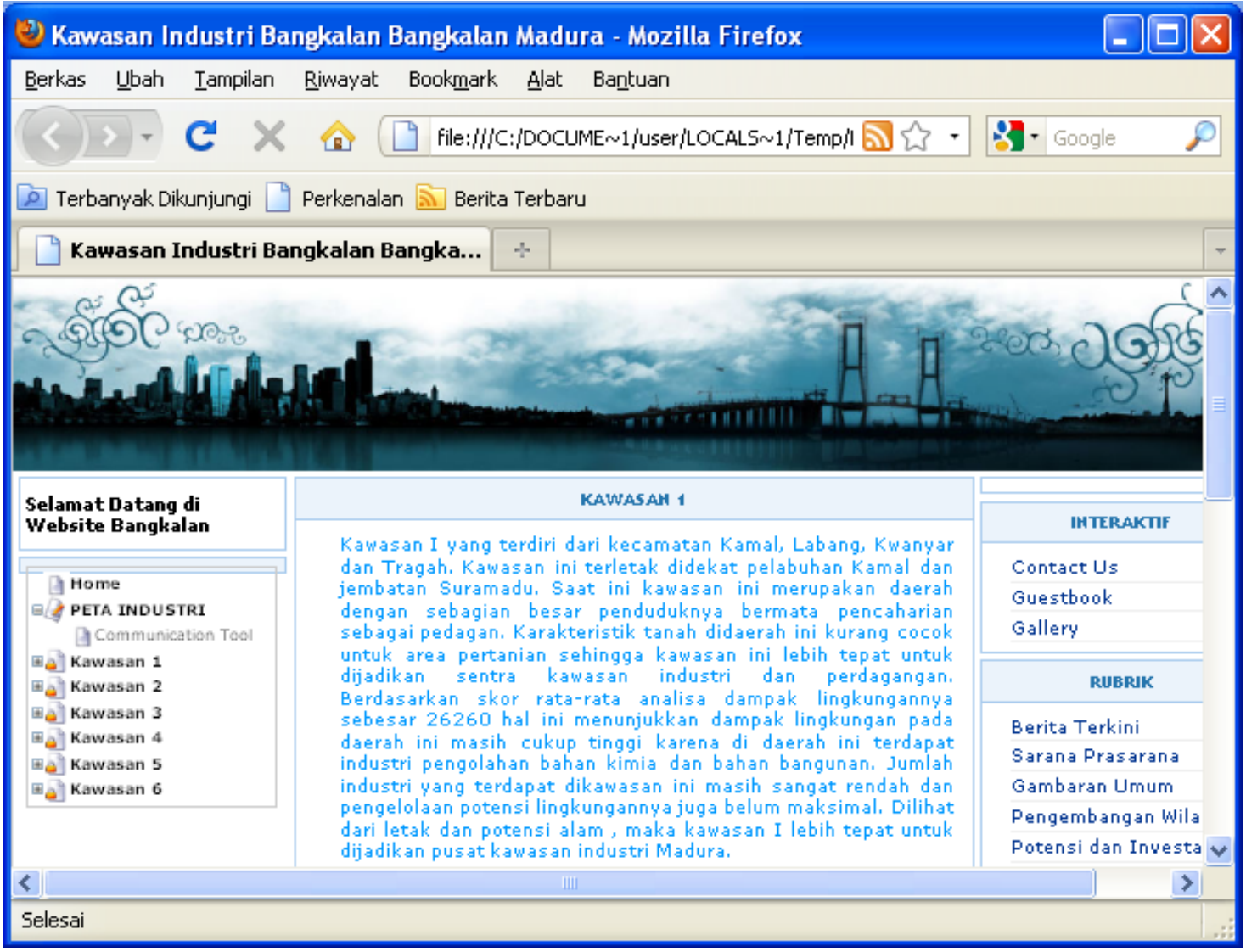

Gambar 4. Model sistem informasi potensi daerah

Produk Krupuk Berbasis Bahan Lokal (Studi Kasus Di Surabaya), Institut Teknologi Sepuluh November

Djajadiningrat, Surna T dan Melia Faniola. 2004. Kawasan Industri Berwawasan Lingkungan. Bandung: Rekayasa Sains

Famiola, Melia. 2003. Analisis Pengembangan Wilayah Industri Karet dengan Menggunakan Pendekatan Klaster Industri. Thesis. ITB

Fitri A, Retno A. 2008. Studi Klastering Wilayah Kecamatan untuk Kawasan Industri Berdasarkan Potensi Sumber Daya Alam dan Sosial Kependudukan (Studi Kasus: Kabupaten Bangkalan, Madura). Penelitian Dosen Muda. Universitas Trunojoyo. Madura

Hair, Jr., Joseph F., et al. 1998. Multivariat Data Analysis (Fifth Edition). New Jersey: Prentice-Hall, Inc.

Hartarto, Airlangga. 2004. Strategi Clustering dalam Industrialisasi Indonesia. Yogyakarta: ANDI Yogyakarta.

Iriawan, Nur dan Septin Puji Astuti. 2006. Mengolah Data Statistik Dengan Mudah Menggunakan Minitab 14. Yogyakarta: Andi Offset.

Jayadinata, Johara T. 1999. Tata Guna Tanah dalam Perencanaan Pedesaan, Perkotaan dan Wilayah (edisi ketiga). Bandung: ITB

Kountur, Ronny D.M.S., Ph.D. 2004. "Manajemen Resiko Operasional". PPM.
Kuncoro, Mudrajad. 2004. Otonomi dan Pembangunan Daerah: Reformasi, Perencanaan, Strategi dan Peluang. Jakarta: Erlangga

Mahadwartha, Putu Anom. 2002. Jurnal Ekonomi dan Bisnis (edisi VIII/2) : Analisa Cluster Saham-Saham Berdasarkan Nisbah Profitabilitas Di Masa Krisis. Salatiga: Fakultas Ekonomi UK. Satyawacana.

Nugroho, Bhuono Agung. 2005. Strategi Jitu Memilih Metode Statistik Penelitian Dengan SPSS. Yogyakarta: ANDI.

Paramita. 2008. Kajian Peningkatan Dukungan Kabupaten Bangkalan sebagai Daerah Lokasi Kegiatan Sektor Industri di Propinsi Jawa Timur Terkait Rencana Pembangunan Jembatan Suramadu. Regional and City Planning Study Programme ITB.

Stanley R.M. Oliveira; Osmar R. Za'iane. Privacy Preserving Clustering By Data Transformation, http://www.cs.ualberta.ca/ zaiane/postscript/sbbd03. $p d f$, 29 Januari 2008, +/- 11:30 WIB.

Simamora, Bilson. 2005. Analisis Multivariat Pemasaran. Jakarta: PT. Gramedia Pustaka Utama

Supranto, J. 2004. Analisis Multivariat: Arti dan Interpretasi. Jakarta: PT. Rineka Cipta.

Stephan, Haimowitz J.D., Jenifer, Urff J.D., and Kevin, Huckshom Ann. September 2006. "Restraint and Seclusion - A Risk Management Guide".

Stantec. Inc., 2001."Risk Management Planning: An Essential QA / QC Tool" Canada. 
Subagya, K. Dampak Pengembangan Kawasan Industri Terhadap Perkembangan Kota di sekitarnya. Program Studi Teknik Arsitektur - Fakultas Teknik. Universitas Budi Luhur

Suratmo, F Gunawan., 1993, "Analisis Mengenai Dampak Lingkungan”, Gadjah Mada University Press.

Risqi Zulkarnaen, Analisa Pembentukan Klaster Pada Sektor Industri Pengolahan Ikan Di Jawa Timur dengan menggunakan Hierarchical Klaster, NonHierarchical Klaster dan CSSF. Tugas Akhir Jurusan Teknik Industri - ITS.

Wulandari. Nuryuliana 2004. Studi Pengelompokan Wilayah Terhadap Kecamatan-kecamatan Tiap Kabupaten di Madura Berdasarkan Variabel Kesehatan. ITS Surabaya. 